\title{
$\mathrm{OH}^{-}$吸着による液液界面電位のナノ LIF 計測
}

\section{Nano-LIF Measurement of Electrostatic Potential at Liquid-Liquid Interface by Adsorption of Hydroxide Ion}

\begin{abstract}
$\bigcirc$ 佐藤 悠 (慶大院)
田部井 祐（慶大院） 正 佐藤 洋平（慶大理工）

Yu Sato, Tasuku Tabei, Yohei Sato and Koichi Hishida

Keio University, 3-14-1 Hiyoshi, Kohoku-ku, Yokohama, 223-8522

The relationship between the $\mathrm{OH}^{-}$concentration of mixing solution and the electrostatic potential at the liquid-liquid interface was investigated. Two kinds of fluorescent dye whose concentration changes depending on the electrostatic potential were introduced in the aqueous solution. An evanescent wave excited the fluorescent dye in the vicinity of the interface, and nano color imaging, which is based on nanoscale laser-induced fluorescence, was used to acquire the fluorescent intensity distribution. The $\mathrm{OH}^{-}$concentration of the mixed solutions was formed to vary spatially, gradually reducing from the side of the higher $\mathrm{pH}$ solution to the lower $\mathrm{pH}$ solution. The result indicates that the electrostatic potential changes depending on the spatial $\mathrm{OH}^{-}$concentration.
\end{abstract}

菱田公一（慶大理工）

Key Words: Liquid-liquid interface, Evanescent wave, Electrostatic potential, Ion motion

\section{1. 緒言}

マイクロチャネル内において化学反応や混合, 分離, 抽 出等の化学的操作は試料溶液の界面で行われる. 比界面積 が大きいことから, 界面の影響が化学的操作に大きく関与 するため界面で発生する現象の把握は重要である．固液界 面では固相の脱プロトン反応により電位が形成されている (1). Kazoe \& Sato はナノスケール・レーザ誘起蛍光法（ナ ノ LIF 法) を開発し, 固液界面電位の二次元分布計測を行 った ${ }^{(2)}$. 液液界面電位に関しては電位形成が確認されてい るが，その形成メカニズムは解明されていない。本研究で は, 液液界面電位形成メカニズム解明に向けて, ナノ LIF 法を用いて液液界面電位と水酸化物イオン濃度との関係を 明らかにする。

\section{2. 原理}

溶液中の界面極近傍のイオン濃度は界面電位により変化 する. 溶液中でイオンとして存在する蛍光色素を用いるこ とで電位に依存したイオン濃度を蛍光強度として計測可能 である. 本研究では，エバネッセント波を励起光として用 いることで界面極近傍における蛍光色素のみを撮像した。 LIF 法において, 励起光強度 $I_{e}$ により蛍光色素を励起した 際の蛍光強度 $I_{f}$ は式(1)を用いて表される。

$$
I_{f}=I_{e}(\lambda) C_{f} \Phi \varepsilon_{f}(\lambda)
$$

$C_{f}$ は蛍光色素の濃度, $\Phi$ は量子収率, $\varepsilon_{f}$ は吸光係数である. 蛍光強度 $I_{f}$ は励起光強度 $I_{e}$ に比例するため, 液液界面のよう な不安定で励起光強度のゆらぎが著しい計測場においてナ ノ LIF 法を用いるのは困難である. 本研究ではナノ LIF 法 を応用させたナノカラーイメージング法(3)を行った. これ は, 2 種類の蛍光色素を用いて各蛍光強度から蛍光強度比 を求める手法であり，その強度比は式(2)に表される.

$$
\frac{I_{f_{-} \text {red }}}{I_{f_{-} \text {green }}}=\frac{I_{e}(\lambda) C_{f_{-} \text {red }} \Phi \varepsilon_{f_{-} \text {red }}(\lambda)}{I_{e}(\lambda) C_{f_{-} \text {green }} \Phi \varepsilon_{f_{- \text {green }}}(\lambda)}
$$

式(2)上り励起光強度のゆらぎの影響を除去することで, 不 安定な界面での電位計測が可能となる. 本研究では, 電離 して 2 価の陽イオンとなる Dichlorotris(1,10-phenanthroline) ruthenium(II)hydrate(Ru(Phen)) (Sigma-Aldrich Co., 励起波長 $450 \mathrm{~nm}$, 蛍光波長 $582 \mathrm{~nm}$ ) と, 2 価の陰イオンとなる Alexa Fluor 488 (Invitrogen Molecular Probes, 励起波長 $490 \mathrm{~nm}$,
蛍光波長 $519 \mathrm{~nm}$ )を選定し，色素間の波長の影響がないこ とを確認している.

\section{3. 計測手法}

3.1 計測システム

計測システムの全体図を Fig. 1 に示す. 励起光源として 半導体レーザ(Coherent Japan Inc., Sapphire ${ }^{\mathrm{TM}} 488-20$, 波長 $: 488 \mathrm{~nm}$, 出力: $100 \mathrm{~mW}$ ) を用いた. レーザ光をピンホール とプリズムを介して Fig. 2 のようにチャネル内の油水界面 で全反射させ, 水相側に染み出たエバネッセント波を励起 光とする.エバネッセント波により励起した蛍光を空浸対 物レンズ(Nikon Corp., Plan Fluor, $4 \times, N A=0.13$ )を通し, 3CCD カメラ(Hamamatsu Photonics K. K., C7780-20, 672 pixels $\times 512$ pixels $\times 12$ bits)で各色素の蛍光波長成分ごとに 撮像した. 本研究でのエバネッセント波の染み込み深さは $83 \mathrm{~nm}$ と算出された。

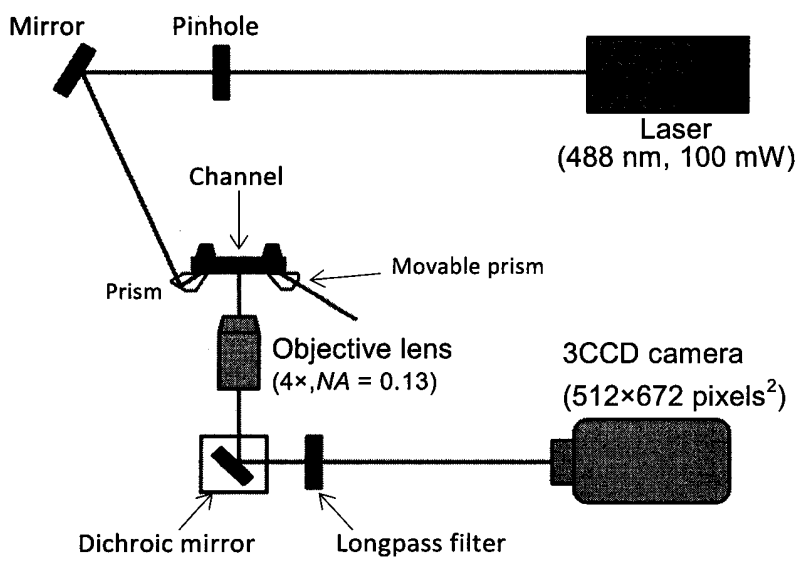

Fig. 1 Schematic of Measurement system.

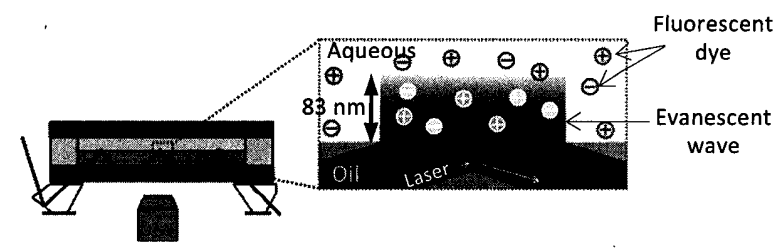

Fig. 2 Evanescent wave illumination system. 
(a)

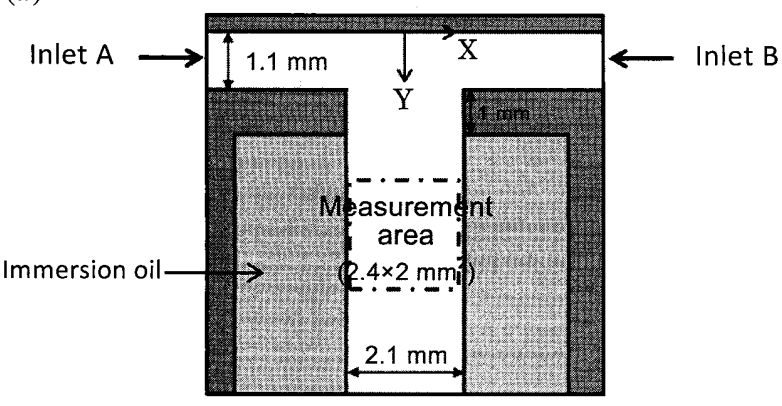

(b)

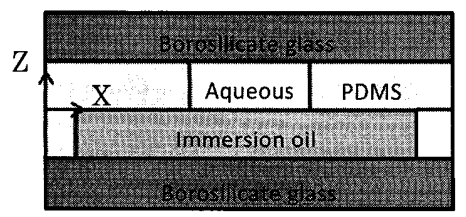

Fig. 3 (a) Top and (b) cross-sectional views of the channel.

\section{2 対象とする溶液}

水相として緩衝液 HEPES を濃度 $5 \mathrm{mmol} / \mathrm{L}$ で混入した $\mathrm{pH} 7$ の溶液と, ほう酸塩 $\mathrm{pH}$ 標準液を濃度 $5 \mathrm{mmol} / \mathrm{L}$ で混入 した $\mathrm{pH} 9$ の溶液を用意した。これは水酸化物イオン濃度が それぞれ $0.1 \mu \mathrm{mol} / \mathrm{L}$ と $10 \mu \mathrm{mol} / \mathrm{L}$ に調整されていることと 同じである。また，これらの溶液には $\mathrm{NaCl}$ を濃度 1.0 $\mathrm{mmol} / \mathrm{L}$ で混入している. 油相にはイマージョンオイル（屈 折率 1.515 , 粘性係数 $0.651 \mathrm{~Pa} \cdot \mathrm{s}$ ) を使用した.

3.3 実験流路

本研究では Fig.2のようにホウケイ酸ガラスと PDMS を 用いた 4 層構造のチャネルを使用した。 $\mathrm{T}$ 字型チャネルの 下部をイマージョンオイルで満たし, 流入口 $\mathrm{A}, \mathrm{B}$ から水酸 化物イオン濃度の異なる溶液 $(0.1 \mu \mathrm{mol} / \mathrm{L}, 10 \mu \mathrm{mol} / \mathrm{L})$ を それぞれシリンジを用いて送液した。 これより水酸化物イ オン濃度が非一様に分布する油水界面を形成した。 ホウケ イ酸ガラスは親水性であるため, 油相と接する最下層のホ ウケイ酸ガラスには OTS 表面修飾を施し親油性に加工し, 安定した液液界面を作成した。 また Fig. 3 の点線に囲まれ た領域を計測領域とし, その大きさは $2.4 \times 2.0 \mathrm{~mm}^{2}$ である。

\section{4. 実験結果および考察}

$\mathrm{T}$ 字型流路の流入口 A から $\mathrm{pH} 9$ の溶液, 流入口 B からは $\mathrm{pH} 7$ の溶液を $10 \mu \mathrm{L} / \mathrm{s}$ で流した. このときの流路の下流 8 $\mathrm{mm}$ から $10.4 \mathrm{~mm}$ における, ナノ・カラーイメージング法 による液液界面極近傍の蛍光強度比の二次元分布を Fig.4 に示す。また, 流路下流 $9.2 \mathrm{~mm}$ における流路垂直方向の 蛍光強度比を Fig. 5 に示寸. Fig. 4,5 から水酸化物イオン濃 度の高い $\mathrm{pH} 9$ から濃度の低い $\mathrm{pH} 7$ にかけて蛍光強度比が小 さくなった。

また, 界面電位值を直接計測するには, 界面電位值と蛍 光強度比の較正曲線が必要である. 電位值を求めるには界 面電位に比例する電気浸透流の速度計測を行わなければな らないが, 本研究では電位に依存して濃度が変化する蛍光 色素を用いている.したがって蛍光強度は電位の関数とし て表され，2 種類の蛍光色素から求めた蛍光強度比は界面 電位に依存しているので蛍光強度比の結果から界面電位に ついての考察が可能となる.

液液界面に形成された蛍光強度比分布から，電位が液液 界面に形成していることが確認できる。これは水酸化物イ オンが界面に吸着したことが原因と考えられる. pH7 の溶

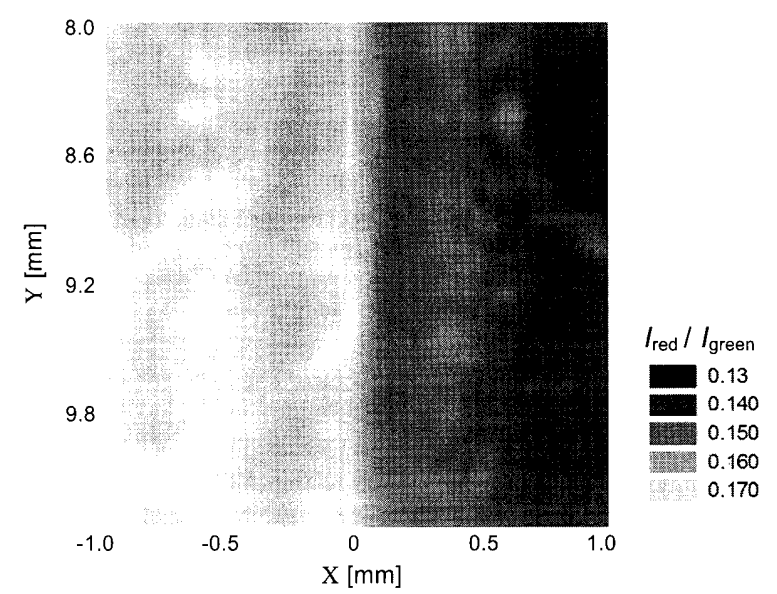

Fig. 4 Intensity ratio $\left(I_{\text {red }} / I_{\text {green }}\right)$ distribution. (left : pH9 solution right : $\mathrm{pH} 7$ solution)

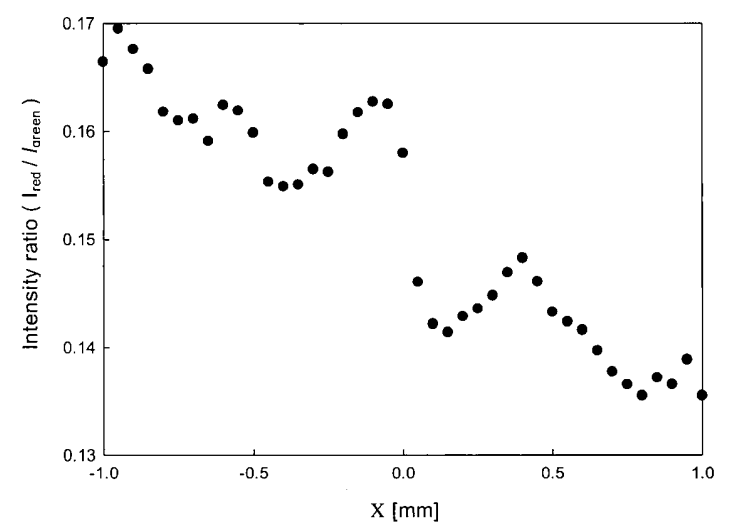

Fig. 5 Profiles of intensity ratio $I_{\text {red }} / I_{\text {green }}$ at $y=9.2 \mathrm{~mm}$.

液では，界面に吸着する水酸化物イオンが $\mathrm{pH} 9$ の場合より も少ないために陽イオンに帯電する赤色蛍光色素の強度が 小さくなり，蛍光強度比が小さくなったと考えられる.

\section{5. 結言}

本研究では, 液液界面電位形成メカニズム解明に向けて, 油水界面上に水酸化物イオン濃度の異なる水溶液の混合場 を形成し，ナノ LIF 法を応用させたナノ・カラーイメージ ング法を用いて界面極近傍の蛍光強度比の二次元分布計測 を行った. 蛍光強度比は界面電位に依存するので, 水酸化 物イオン濃度が $0.1 \mu \mathrm{mol} / \mathrm{L}$ の溶液と $10 \mu \mathrm{mol} / \mathrm{L}$ の溶液の蛍 光強度比の比較から, 水酸化物イオン濃度が高いと界面電 位が負に増大すると考えられる. 以上により蛍光強度比分 布の計測から水酸化物イオン濃度と液液界面電位の相関関 係が解明された。

\section{参考文献}

(1) Kirby, B.J. \& Hasselbrink, Jr., E.F., Electrophoresis, 25 (2004), 187-202.

(2) Kazoe, Y. \& Sato, Y., Anal. Chem., 79 (2007), 6727-6733.

(3) Kazoe, Y. et al, Appl. Phys. Lett, 95, (2009), 234104.

\section{謝辞}

本研究を行うにあたり，(独)日本学術振興会科学研究費 補助金・基盤研究（S）（No. 21226006）の助成を受けた. 